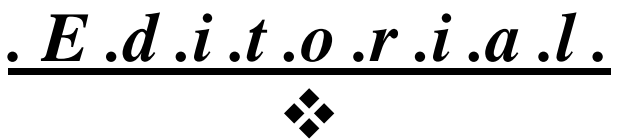

\section{Dossiê Temático sobre Representações e Práticas Sociais}

\author{
Dossier Temático sobre Representaciones y Prácticas Sociales \\ Thematic Dossier on Social Representations and Practices
}

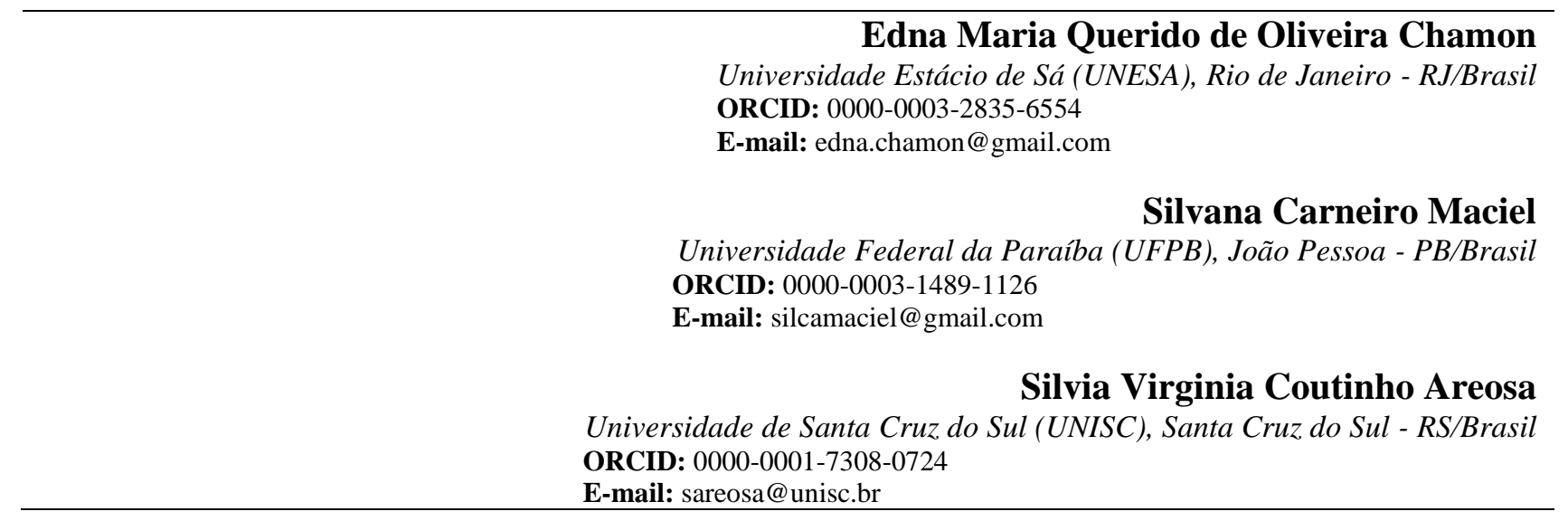

O Periódico, PSI UNISC, é uma revista vinculada ao Programa de Mestrado Profissional em Psicologia da Universidade de Santa Cruz do Sul (UNISC) e publica produções científicas nas temáticas das áreas da Saúde Mental e Práticas Sociais que privilegiam pesquisas e discussões na interface entre a Psicologia e os processos clínicos e sociais. O periódico está indexado em bases nacionais e internacionais trazendo relevantes contribuições para a ciência e, neste número, se dedica a fazer um Dossiê temático sobre a Teoria das Representações Sociais e as práticas sociais.

A Teoria das Representações Sociais (TRS) foi introduzida na Psicologia em 1961, com o estudo do pesquisador francês, nascido romeno, Serge Moscovici sobre o fenômeno da socialização da psicanálise e da sua apropriação pela população parisiense, intitulado La Psychanalyse, son Image et son Public. Esse estudo introduz o conceito de representação social como a base dos processos de apreensão de um conhecimento novo por um grupo, nesse caso uma nova teoria científica. Assim, a representação social da psicanálise é a reconstrução, elaborada no grupo (isto é, socialmente) da teoria psicanalítica.

A proposição da teoria da representação social constitui um questionamento forte da psicologia social da época, particularmente da tradição americana (Farr, 1992). Para o autor esta serve como um alicerce das identidades e, assim pode ser entendida como o ponto de partida para as diferenças, e refere que as "representações estão presentes tanto 'no mundo' como 'na mente'" (Farr, 1994, p. 46).

Na realidade, a TRS surgiu em oposição à Psicologia Social da época, a qual, no entender de Moscovici (1961/1978), tinha uma perspectiva muito individualista, uma vez que concebia o social como a simples presença real ou imaginária de outros indivíduos nos processos psicológicos individuais. E foi também bastante influenciado por uma visão comportamental e cognitivista. Frente à perspectiva individualista ou "psicologista" da psicologia social da época, Moscovici buscou um primeiro apoio conceitual na concepção do sociólogo Durkheim de Representações Coletivas. No 
entanto, dá um passo adiante e ressalta a importância de se considerar tanto os comportamentos individuais quanto os fatos sociais dentro do seu contexto histórico mais amplo. Ele destaca a necessidade de se ver a relação entre o social e o individual; a participação do indivíduo na construção da sua realidade social, construindo um novo campo de ação que estaria na intersecção dos dois, na forma da psicossociologia.

Moscovici propõe olhar aquilo que circula nas comunicações de um grupo de indivíduos como uma forma de conhecimento: o conhecimento do senso comum. A TRS se propõe a compreender de que maneira esse conhecimento de senso comum se molda, se organiza e se interrelaciona com as práticas sociais de um grupo, construindo uma orientação a priori e uma justificação a posteriori para o comportamento social.

Atualmente, o estudo das representações sociais tornou-se um campo muito vasto de pesquisa, englobando uma extrema variedade de assuntos, haja vista as representações sociais estarem relacionadas a muitos objetos sociais e serem transmitidas através da comunicação, podendo ocorrer em qualquer lugar onde as pessoas se comunicam, situando-se na interface do individual e do social. Vala (2000), em relação a isso, destaca que, uma vez criada uma representação acerca de um outro, esta passa a constituir esse outro e a orientar a interação de forma a atribuir foros de realidade ao que é representado. Destaca, ainda, que as representações são fatores produtores da realidade com repercussões na forma como o indivíduo interpreta o que acontece a ele e ao seu redor, determinando as respostas que encontra para fazer face ao que julga ter acontecido (justificação). De tal modo que, uma vez constituída uma representação, os indivíduos procurarão criar uma realidade que valide as precisões e explicações decorrentes dessa.

Observa-se, pois, que a Teoria das Representações Sociais é ampla estando as mesmas impregnadas de várias noções como atitudes, opiniões, estereótipos, ideologias, crenças, práticas sociais entre outras; daí que muitos pesquisadores lançam mão destas e de outras noções de forma a melhor situar seus estudos no nível do esclarecimento de fenômenos mais coletivos.

Os estudiosos da TRS visam compreender por que alguns problemas sobressaem numa dada comunidade, observando alguns aspectos de sua apropriação pela sociedade; além de permitir compreender de que forma certos objetos sociais escolhidos constituem o foco de condutas múltiplas e complexas, as quais são desenvolvidas entre diferentes grupos de atores.

Para Spink (1994) a representação aparece basicamente em sua função de estrutura, entretanto, como estrutura estruturante, as representações sociais oferecem matrizes sobre as quais o pensamento trabalha. Ainda afirma que ao serem propostas como interface entre sujeitos e objetos, as representações assumem o estatuto de ambiente de pensamento.

Além de seu interesse teórico, ligado ao fenômeno das representações sociais e como se constróem e se movimentam essas formas específicas de conhecimento - sua gênese, sua lógica, sua dinâmica -, a TRS apresenta também um interesse prático de alta relevância: ela abre caminhos para a compreensão das influências recíprocas entre as representações e as práticas sociais, lançando novas luzes sobre o como e o porquê do comportamento social.

Almeida, Santos e Trindade (2000) fazendo uma análise sobre as práticas sociais destacam que mesmo que não seja algo de interesse exclusivo das Representações Sociais existe uma relação muito forte entre elas, muito embora existam dificuldades metodológicas entre elas. Outros pesquisadores da TRS como Abric (1994) também ressaltam algumas evidências nas relações entre representações e práticas sociais; seja as representações determinando as práticas ou sendo determinadas por ela, defendendo que há uma relação de interdependência entre elas, em um caráter dialético. 
Nesta direção Arruda (2014) nos lembra que o estudo da dinâmica das Representtações Sociais (RS) foi inaugurada por Flament, seguido por Rouquette e Moliner, nos estudos sobre a perspectiva estrutural (núcleo central e periférico vinculado a outros intervenientes como as práticas sociais. Ressaltando que a dinâmica de que se fala está relacionada a movimentos, regulações e práticas sociais que além de desenhar a representação conferem, a esta, plasticidade.

Em tempo, relembramos que Moscovici (1961/1978), no seu trabalho inaugural sobre TRS, fala sobre os sistemas de comunicação (emissor/receptor), permitindo compreender os conteúdos das representações e das práticas sociais circundantes na sociedade, já mostrando desde então a importância do conhecimento das práticas sociais relacionadas as representações. Diante disso, neste dossiê os pesquisadores farão a articulação entre a TRS e as Práticas Sociais, com as mais distintas formas de metodologias e uma pluralidade de objetos sociais, o que faz deste dossiê um fecundo objeto de conhecimento científico, com amplo espectro de aprendizado. Por isso, convidados todos vocês a percorrerem os artigos aqui expostos com um olhar dialógico entre as representações e as práticas sociais.

Uma excelente leitura para tod@s!

\section{Referências}

Abric, J.C. (1994). Pratiques sociales et representations. Paris: Presses Universitaires de France.

Almeida, A.; Santos, M. F. S. \& Trindade, Z. A. (2000). Representações e práticas sociais: contribuições teóricas e dificuldades metodológicas. Temas em Psicologia, 8(3), 257-267. Recuperado de http://pepsic.bvsalud.org/scielo.php?script=sci_arttext\&pid=S1413$389 \times 2000000300005 \& \operatorname{lng}=\mathrm{pt} \& \operatorname{tlng}=\mathrm{pt}$

Arruda, A. (2014). Representações Sociais: dinâmicas e redes. In A. M. O. Almeida, M. F. S. Santos \& Z. A. Trindade (Orgs.), Teoria das Representações Sociais: 50 anos (2 ed., pp. 442-491). Brasília, DF: Technopolitik.

Farr, R. M. (1992). Les représentations sociales: la théorie et ses critiques. Bulletin de psychologie, XLV (405), 183-188.

Farr, R. (1994). Representações sociais: A teoria e sua história. In P. Guareschi \& S. Jovchelovitch (Orgs.), Textos em representações sociais (2a ed., pp. 31-59). Petrópolis, RJ: Vozes.

Moscovici, S. (1961/1978). A representação social da psicanálise. Rio de Janeiro: Zahar.

Spink, M. J. (1994). Desvendando as teorias implícitas: Uma metodologia de análise das representações sociais. In P. Guareschi \& S. Jovchelovitch (Orgs.), Textos em representações sociais (2a ed, pp. 117-145). Petrópolis, RJ: Vozes.

Vala, J. (2000). Representações sociais e psicologia social do conhecimento quotidiano. In: Vala, J. \& Monteiro, B. (org.), Psicologia Social (pp. 457-502). Lisboa: Fundação Calouste Gulbenkian. 